kaja hazieta, 18 July 1946; 'Ab biełaruskim pravapisie', Litaratura $i$ mastactva, 31 July 1948; M. R. Sudnik, 'Składanyja słovy u biełaruskaj arfahrafičnaj sistemie', Litaratura $i$ mastactva, 2 October 1948; S. Turčynovič, B. Piatrovič, 'Inšamoŭnaja i internacyjanalna - revalucyjnyja słovy', Litaratura i mastactva, 25 September 1948.

71. For a summary of the proceedings of this conference see: I. A. Ossovetskij, 'Voprosy sovremennoj belorusskoj orfografii', Voprosy jazykoznanija, Moscow, 1952, 2, pp. 151-5. A more detailed exposition of the proposals in the 1951 prajekt may be found in $\mathrm{K}$. K. Krapiva, 'Pytańni biełaruskaha pravapisu u śviatle vučeńnia I. V. Stalina ab movie', Vieści Akademii Navuk BSSR, Minsk, 1952, 2, pp. 24-37 (reprinted, without the references to Stalin, as 'Pytańni bielaruskaha pravapisu' in: Kandrat Krapiva, Zbor tvora ŭ $u$ piaci tamach, vol. 5, Minsk, 1976, pp. 170-88).

72. Pastanova Ab udakładnieñni i častkovych żmienach isnujučaha biełaruskaha pravapisu, zaćvierdžanaja Savietam Ministraŭ BSSR 11 maja 1957 h. (published in Źviazda, 23 May 1957).

\title{
The Chairman's Annual Report for the Year 1976-1977
}

In the course of its 11 th session, the Society continued its traditional activities of organising lectures and distributing publications. Membership has remained static during the past year, but the Society's contacts with graduates, students and other persons interested in Byelorussia have continued to develop.

The financial affairs of the Society continue to be conducted on a satisfactory basis, thanks to an increase in the sale of publications, and in particular to a welcome grant from the Byelorussian Charitable Trust amounting to a total of $£ 1,436.00$. Generous donations from the Byelorussian Social Clubs in Manchester and Bradford have been of great assistance in enabling us to publish the works of our growing circle of friends in academic life. With income at $£ 2,290$ and expenditure at $£ 2,220$, there remains a surplus for the year of $£ 70$.

Among projects discussed during the session was the question of the Auberon Herbert memorial plaque, a design for which has now 
jeen produced and approved. It is hoped to find a suitable place in sne of the Byelorussian houses in London where it can be erected. Ine design incorporates the emblem of the Society, with which Mr Herbert was associated for twenty years, together with his own armorial bearings.

During the past year a further number of the Journal of Byelo-ussian Studies (Vol. III No. 4) appeared, thus completing another :olume of our publication - the most extensive to date under the editorship of Mr Dingley, with over 431 pages, and articles from more inan twelve contributors. The first number of the fourth volume is in preparation and will be going to press in late 1977 or early 1978 . The circulation of the Journal, organised by $\mathrm{Mr}$ Michaluk, now amounts to over 600 copies each year.

The Eleventh annual course of lectures took place at the Francis Skaryna Byelorussian Library. Our thanks are due to the Librarian Fr Nadson, not only for permission to use the library facilities, but also for the unstinting hospitality which he most kindly provides to members after the lectures, and which so greatly contribute to making the sessions a success. As in the past six papers were read. On the 9th December the Hon. Secretary addressed the Society on the subject of "Heraldic motifs in early printed books". Fr Alexander Nadson dealt with "Aspects of Byelorussian paleography" on 27th January. "Byelorussian influences on Russian 17th century architecture" were a novel aspect of Byelorussian culture examined by Dr Lindsey Hughes of Reading University in a talk given on 24th February. Peter Mayo from the University of Sheffield addressed the Society on "Byelorussian orthography in the 20th century" on 21st April, and James Dingley dealt with the related subject of "Language policy in Soviet Byelorussia" on 19th May. Our long-standing friend, Dr Richard A. French wound up the session on 16 th June with a lecture of "Polack-land in the 16th century". Attendances varied between 28 and 21 with an average number of 24 members and guests. A further lecture course is being organised to take place during the coming session.

A number of members of the Society will be attending the Interna:ional Congress of Slavists in Zagreb in September 1978. Professor McMillin will be presenting a paper on the poet Maxim Bahdanovič, and Shirin Akiner a paper on Oriental borrowings in the language of the Byelorussian Tatars.

The Council of the Society met on the 8th December 1977 to deal with the day to day business of the Society and to consider a programme for future activities.

In concluding, I should like to express my thanks to my fellow Council members for the considerable work they have done during the past years, as well as to our lecturers, and to the members of the Society who have given us their support and helped to make this session a particularly successful one.

\section{John Jolliffe}

Chairman. 